\title{
Contributions of Jean Watson's theory to holistic critical thinking of nurses
}

\author{
Contribuições da teoria de Jean Watson ao pensamento crítico holístico do enfermeiro \\ Contribuciones de la teoría de Jean Watson al pensamiento crítico holístico del enfermero
}

\section{Fernando Riegel', Maria da Graça Oliveira Crossetti', Diego Silveira Siqueira'}

' Universidade Federal do Rio Grande do Sul. Porto Alegre, Rio Grande do Sul, Brazil.

\section{How to cite this article:}

Riegel F, Crossetti MGO, Siqueira DS. Contributions of Jean Watson's theory to holistic critical thinking of nurses. Rev Bras Enferm [Internet]. 2018;71(4):2072-6. DOI: http://dx.doi.org/10.1590/0034-7167-2017-0065

Submission: 03-14-2017_Approval: 08-20-2017

\begin{abstract}
Objective: to reflect on the contributions of Jean Watson's theory to the nurses' holistic critical thinking. Method: This is a theoretical reflection article, on which scientific productions about Jean Watson's human care theory, published in national and international periodicals, were based. Results: Jean Watson's theory and its contribution to the nurses' holistic critical thinking; the interface of critical holistic thinking in teaching the nursing diagnosis process according to Watson's theory; contributions of critical holistic thinking to the nursing field. Final considerations: Jean Watson's theory is based on the humanistic aspects and on the ethical and spiritual dimensions of care, considering the characteristics of each individual and their bio-psycho-spiritual-social needs, which can contribute fundamentally to the development of holistic critical thinking and to the role of the nurse in care, teaching and research fields
\end{abstract}

Descriptors: Thought; Nursing Theory; Nursing Processes; Nursing Diagnosis; Nursing Care.

\section{RESUMO}

Objetivo: refletir acerca das contribuições da teoria de Jean Watson ao pensamento crítico holístico do enfermeiro. Método: trata-se de um artigo de reflexão teórica, para a qual serviram de base produções científicas sobre a teoria do cuidado humano de Jean Watson publicadas em periódicos nacionais e internacionais. Resultados: a teoria de Jean Watson e sua contribuição para o pensamento crítico holístico do enfermeiro; a interface do pensamento crítico holístico no ensino do processo diagnóstico de enfermagem à luz da teoria de Watson; contribuições do pensamento crítico holístico para o campo da enfermagem. Considerações finais: a teoria de Jean Watson baseia-se nos aspectos humanísticos e nas dimensões espirituais e éticas do cuidado, levando em conta as características de cada indivíduo e suas necessidades biopsicossocioespirituais, o que pode contribuir fundamentalmente para o desenvolvimento do pensamento crítico holístico e para a atuação do enfermeiro no campo do cuidado, do ensino e da pesquisa.

Descritores: Pensamento; Teoria de Enfermagem; Processos de Enfermagem; Diagnóstico de Enfermagem; Cuidados de Enfermagem.

\section{RESUMEN}

Objetivo: reflexionar acerca de las contribuciones de la teoría de Jean Watson al pensamiento crítico holístico del enfermero. Método: se trata de un artículo de reflexión teórica, para la cual sirvieron de base producciones científicas sobre la teoría del cuidado humano de Jean Watson publicadas en periódicos nacionales e internacionales. Resultados: la teoría de Jean Watson y su contribución al pensamiento crítico holístico del enfermero; la interfaz del pensamiento crítico holístico en la enseñanza del proceso diagnóstico de enfermería a la luz de la teoría de Watson; contribuciones del pensamiento crítico holístico al campo de la enfermería. Consideraciones finales: la teoría de Jean Watson se basa en los aspectos humanísticos y en las dimensiones espirituales y éticas del cuidado, teniendo en cuenta las características de cada individuo y sus necesidades bio-psico-socio-espirituales, lo que puede contribuir fundamentalmente al desarrollo del pensamiento crítico holístico y para la actuación del enfermero en el campo del cuidado, de la enseñanza y de la investigación.

Descriptores: Pensamiento; Teoría de Enfermería; Proceso de Enfermería; Diagnóstico de Enfermería; Atención de Enfermería.

\section{CORRESPONDING AUTHOR Fernando Riegel E-mail: friegel@hcpa.edu.br}




\section{INTRODUCTION}

This reflection was based on the Delphi study, developed by Facione, the human care theory, by Watson, the assumptions of Capra about the holistic paradigm in health and the basic human needs theory, by Wanda Horta, with emphasis on the psychobiological, psychosocial and, especially, psycho-spiritual aspects, contributing with holistic care performed by a nurse. We sought to include in this reflection the relation between Watson's theory, Wanda Horta's theory and Facione's theoretical reference bout holistic critical thinking. The positive results of this theoretical association became evident in the formation of nurses capable to think holistically and exercise nursing holistic care.

So, we should emphasize that the nurse academic education model in Brazil is guided by the Brazilian National Curricular Guidelines (DCN - Diretrizes Curriculares Nacionais) ${ }^{(1)}$. These guidelines define the principles, foundations, conditions and procedures established by the Higher Education Board of the Brazilian National Council of Education for the formation of nurses at national level, as well as for the organization, development and evaluation of pedagogical projects of the undergraduate nursing schools at higher education institutions.

According to the DCN, the profile of undergraduate student, when graduated/professional, should be that of nurse with a generalist, humanistic, critical and reflexive education. The professional must be qualified to nursing practice based on scientific and intellectual rigor and based on ethical principles, being able to know and intervene on the most prevalent health-disease problems or situations in the national epidemiological profile, with emphasis on the region of performance, identifying the biopsycho-social dimensions of its determinants. Consequently, the nurse must be able to act with social responsibility and commitment to citizenship, promoting the integral health of humans ${ }^{(1)}$.

The objective of this professional formation profile, the DCN are structured in the following general skills and abilities: health care, decision-making, communication, leadership, administration and management, and permanent education. Therefore, the contents to be addressed in the curriculum of the undergraduate courses must include the biological and health sciences, the human and social sciences and the nursing sciences, including the nursing fundamentals, nursing care, nursing administration and the nursing teaching ${ }^{(1)}$.

Currently, the formation of nurses requires reflection on the changes in the epidemiological profile and on the complexity of the care required by patients. In this scenario, we can note gaps in nurses' formation, which has led professionals to apply the nursing process with strong influence of the biomedical model, centered exclusively on physiological changes, giving little emphasis to the humanistic and spirituality aspects of the people under their care. Thus, it substantially interferes in the recovery of patients.

Many nursing curricula remain focused only on content delivery and display of skills instead of supporting human development of nursing students However, we can note that some nursing schools in the country have been breaking with this dominant paradigm, including in its curriculum subjects capable of meeting the demands so necessary for the formation of nurses in Brazil and in the world.
Therefore, we assume that such curricular configurations can also be influenced, being associated to the different understandings of the direction of nursing schools regarding the $\mathrm{DCN}$, considering that, although it brings in its content terminologies such as humanistic aspects and humanistic formation, the document does not identify these terminologies in order to guide the approach of institutions.

Thereby, the importance of the theoretical and philosophical bases of the nursing profession as science and art is identified, which should permeate the fundamentals of the nurses' formation, who must know and apply in their professional practice the nursing theories and philosophy, important subjects that give the necessary subsidies to the nursing process in all its stages, with quality and safety to the patient.

The lack of clarity regarding theories and philosophy in nursing by the nursing schools can contribute to the devaluation of this subject, which has great importance for the holistic critical thinking of the nursing schools' graduates

To add this philosophical aspect essential to the nurses' formation - and not leave it to be understood, or that its inclusion in the curricula be at the discretion of the courses - we suggest modifying the DCN text. The fact that the current guidelines were created approximately 15 years ago and require revision must be considered, so we can be able to instruct nurses to meet the demands and the complexity of the Brazilian health care system.

To meet this formation demand, the human care theory proposed by Watson is fundamentally emphasized, aiming to value the nursing philosophy and the humanistic dimensions that permeate patient care in the different contexts and scenarios of nursing care. This theory has special emphasis in nursing education process, being defined as a methodological tool and a valuable technology that must be used to ensure safety in nursing practice and nursing diagnosis process (NDP). Human care theory is characterized by application of critical thinking and the continuous decision-making in situations that require from the nurse the assessment and the solution of individuals health problems in their care ${ }^{(2)}$.

To cover this work dimension of nurses, the critical thinking (CT), defined as the art to think about thinking, the thinking structured by behavioral and cognitive skills, mind habits ${ }^{(2)}$ becomes essential.

We can assume that the students and nurses who know Watson's human care theory (and apply in their practice) can qualify and develop critical thinking in a holistic perspective. Such awareness becomes fundamental facing changes in the epidemiological profile of individuals, in the prevalence of chronic diseases and in the increasing advances of technological devices and the high-tech environment, with the insertion of robotics and other artificial intelligence technologies. The improper use of these devices can greatly influence the execution of technical care. Given this context, we must reaffirm the need to approach aspects related to beliefs and values, spirituality and to different cultures, understanding the human being in their entirety, giving accuracy and reliability to the NDP.

In this perspective, the holistic paradigm proposes the union between body and mind; however, the mind should not be educated or understood, only controlled. There are many possibilities for us to (re) learn how to work with our body and mind connected, aiming at the integral teaching and learning(3).

In the holistic approach, the nursing and health professionals must contextualize the disease, showing the patient the multiple 
factors that led to dysfunction and teaching him about the nature and meaning of their illness. The professionals must show the patient how they can change the lifestyle that led to the illness. This approach aims to restore full health, and not purely combat the disease by removing its signs and symptoms ${ }^{(3)}$.

\section{JEAN WATSON'S THEORY AND ITS CONTRIBUTION TO THE HOLISTIC CRITICAL THINKING OF NURSES}

Watson's human care theory says that it is essential for the society to maintain the ideals of human care. This is relevant since, daily, there is a proliferation of treatments and radical healing techniques that commonly disregard the human aspects that involve authentic care ${ }^{(4)}$.

The logic of thought proposed by Watson can be developed when formation spaces trigger, by education, the motivation for the thought modeling, so it can handle the humanistic dimensions so necessary in this stagnant and purely technical scenario. In addition, the thought may also face the paralysis of human interaction in the States of greater fragility, where egocentrism and prescriptive care prevail, without giving voice to the subject who pleads for care.

To support this paradigm shift and break with the dominant patterns, thinking critically about care, it stands out the importance of Watson's theory, Wanda Aguiar Horta's theory and publications of authors such as Capra and Facione. These theoretical contributions help in the formation and modeling of nurses' critical holistic thinking, pressing for the current moment.

In this sense, Watson developed in her human care theory, ten charitable factors considered care needs specific to human experiences and that should be addressed by nurses: humanistic and altruistic values system; faith and hope; sensitivity to oneself and others; development of aid, trust and care relations; expression of positive and negative feelings and emotions; creative and individualized care process of troubleshooting; transpersonal teaching and learning; nurturing, protective and/or corrective, mental, physical, social and spiritual environment; assistance to human needs and existential-phenomenological and spiritual forces ${ }^{(5)}$.

The charitable factors proposed by Watson meet what Wanda Aguiar Horta proposed in her theory of basic human needs, especially regarding the psycho-spiritual needs of the human being. It also dialogues with what Capra proposes presenting the human being as a living and dynamic system, composed of larger systems, interconnected and interdependent, in which the physical, mental, social and spiritual dimensions should be considered ${ }^{(6)}$.

In this context, the human thought often, as well as the habit of thinking critically, can be influenced by Watson's theory, giving it the status of holistic thinking, because the human being is now understood as a living and greater system, and its elements are interconnected and interdependent.

In this perspective, as a positive result of thinking holistically, nurses contextualize patients with the framework that involves the disease, allowing the visibility of the actual state of health and the factors that led them not to be healthy. In addition, this holistic thinking brings together professionals in order that no underestimate the degenerative organic State, but which also include the spiritual practices of State care, considering the balance between mind-body-spirit taught by Watson ${ }^{(6)}$.

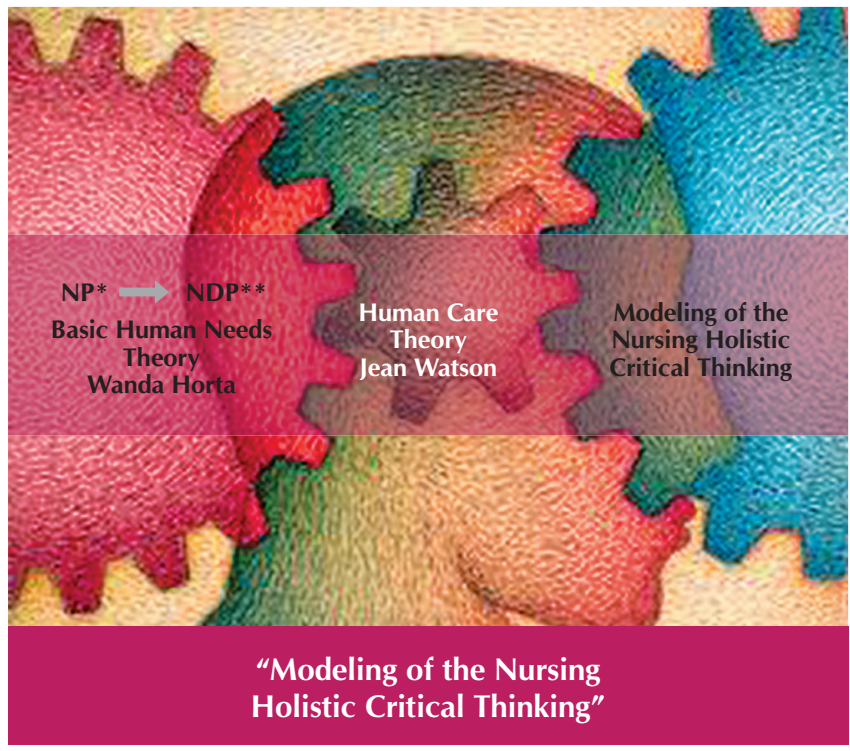

Source: adapted from the website Estado de Direito. Available at https:/goo.gl/ x6KAe5. Access on 28 fev. 2018.

Notes: * NP: nursing process; ** NDP: nursing diagnosis process.

Figure 1 - Modeling of nursing holistic critical thinking based on Watson, Horta and Facione

\section{HOLISTIC CRITICAL THINKING INTERFACE IN TEACHING OF NURSING DIAGNOSTIC PROCESS ACCORDING TO WATSON'S THEORY}

The NDP is the fundamental element for decision-making of the nurse, because it evidences the actual health conditions of individuals, enabling the identification of the priority nursing diagnosis, including the proper interventions for achieving the expected results ${ }^{(7)}$.

Critical thinking is an essential aptitude in NDP and is defined as an intentional judgment that results in interpretation, analysis, evaluation and inference, as well as an explanation of the evidence on which the judgment was based. Such action requires skills moved by reason, mental habits and emotional aspects that involve human relations facing the need to make immediate clinical decisions, affecting the quality of the provided care (8).

Regarding the teaching of NDP, human care theory allows the nurse to consider the patient's life trajectory and experiences, including the ethical, aesthetic and personal context. Therefore, the nurse must learn to diagnose. Watson's theoretical foundation assists in the development of important mind skills and habits for a good holistic critical thinker, such as: understanding, trust, creativity, intuition, contextual perspective, and reflection, which lead this thinker to consider the historical bio-psychosocial context and cultural context of the patient, holistically seeing the human being under his care. So, the students feel more successful and express higher levels of satisfaction ${ }^{(5)}$.

In this context, we can understand that the human care theory can fill in the gaps of the holistic nurse formation, since, in nursing education, there are still shortcomings especially regarding the application of holistic and spiritual dimension. Would these shortcomings reflect the current approach of the subject by the $\mathrm{DCN}$ ? Would they reflect the absence of definitions of what is 
essential for the nurses' formation? Faced with such questions, to elaborate guidelines that will guide the inclusion of these subjects as transversal in the political-pedagogical projects of nursing undergraduate schools in Brazil is increasingly necessary, expanding the holistic and human view of the graduates of the nursing field.

From the analysis of the document that limits the national guidelines for nursing courses (DCN), we identified that the humanistic aspects involving nursing care are present in some of the items in the document ${ }^{(1)}$; however, the DCN do not mention the subject between its paragraphs. Therefore, the approach to the humanization subject becomes superficial, not presenting definitions for terms such as "humanistic formation", "humanistic dimensions", "humanistic principles of the profession and inherent to care", "humanistic commitment" and "humanization of care" .

So, we need to discuss the proposal of holistic education to contribute to the inclusion of holistic and spiritual subject in nursing education. This inclusion is extremely timely, since these subjects seek to restore the balance between the linear thinking and intuition, which takes place in the classroom by various techniques: case studies, realistic simulation and other strategies for active methodologies in which the student can experience real situations in high complexity laboratories ${ }^{(2)}$.

We believe that Watson's and Horta's theories can support critical thinking effectively, giving it the status of holistic critical thinking - a thought that should be modeled in the formation process, so that the future nurse is prepared to signify the findings relating to spirituality, beliefs and values of the individuals who they will assist in their daily work. So, this professional has the possibility to think better.

Those theories can redefine the NDP, showing basic humanistic needs that are often in the background because they are not connected directly to a physiological organic problem, which, in the medium and long term, can trigger visible physiological changes.

\section{HOLISTIC CRITICAL THINKING CONTRIBUTIONS TO THE NURSING FIELD}

Considering the nature of nursing, characterized for being a social and humanistic discipline that combines science and care of individuals with complex problems, nurses and nursing students need to be introduced in holistic critical thinking on the diagnostic process application. It assumes paramount importance because nursing diagnoses and interventions should be directed to the human being in their entirety.

Holistic critical thinking can be defined as the quality thinking, that is, it is about the judgement process centered on deciding what to believe or what to do; for this, the critical thinker should not be negative or cynical, but reflective and balanced, requiring people to express reason or basis for what they are saying ${ }^{(9)}$.

Facione claims that the application of HCT requires knowledge, experience and critical thinking, combined with cognitive and behavioral characteristics. Among these characteristics, we should highlight: analysis, standard application, discernment, explanation, inference, interpretation, prediction, knowledge transformation, self-confidence, open-mindedness, research and mind habits such as intuition, understanding, confidence, creativity, curiosity, intellectual integrity, perseverance, contextual perspective and reflection, as well as other emotional and relational skills ${ }^{(9)}$.

So, we observe that the holistic approach contributes to the development of critical thinking. Therefore, the change in dominant paradigms, regarding linear thinking, can represent an interface in the nursing field, both in care/assistance and in teaching and research, qualifying the different nurse's lines of action, to resolve human dimensions involving the being and the doing in nursing (Figure 2).

When thinking holistically, a willingness is necessary to pursue open-mindedness and intellectual honesty in identifying reasons and evidence for making objective decisions and resolving complex, high-risk or poorly structured problems, anticipating possible consequences, and being prudent ${ }^{(9)}$.

The ability to use these mind habits will be decisive in the implementation of the NDP, because such habits may consider the entirety of the care with a larger view of reality and of the uniqueness of individuals. Bringing this discussion to the practical field, means that, in the daily care, the individual will be genuinely assisted, meeting all their needs, including the human and spiritual dimensions.

The CT can be considered as an intentional and self-regulating judgment resulting from interpretation, analysis, evaluation and inference, as well as explanations of the evidence, of conceptual, methodological and contextual considerations or criteria, on which the judgment was based ${ }^{(10)}$. In this perspective, we can understand that the HCT can further qualify the practices in different scenarios, in which the nurses were inserted. This resonance can be displayed in the figure below:

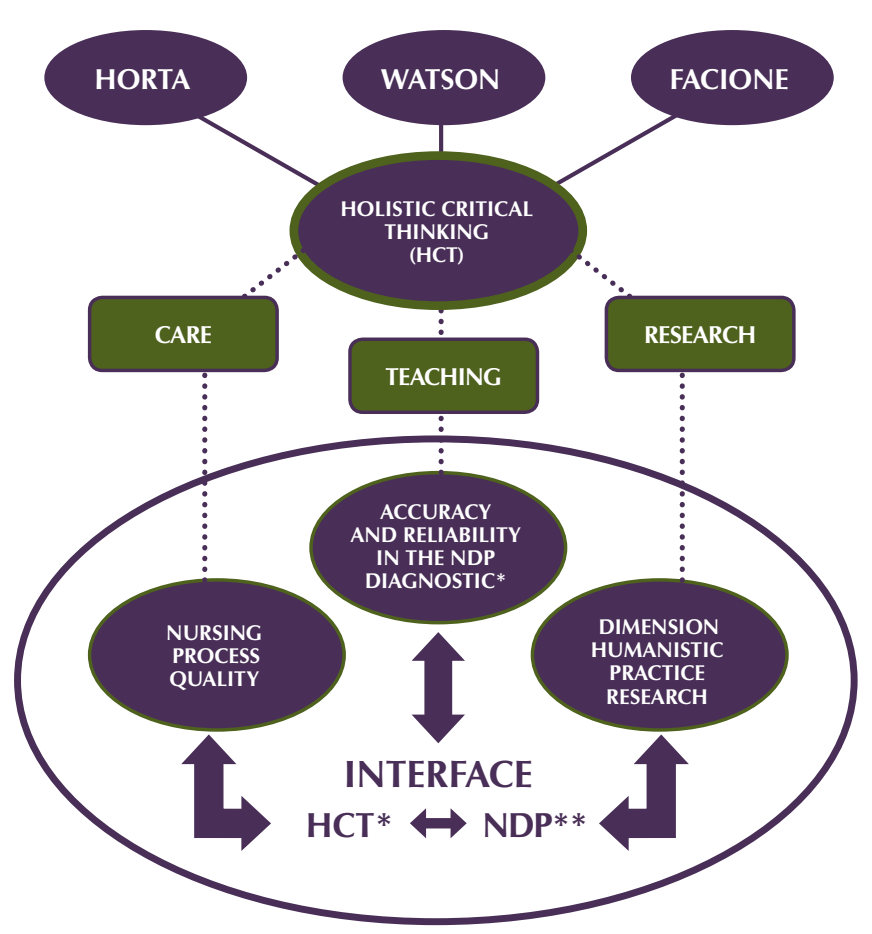

Notes: * HCT: holistic critical thinking; ** NDP: nursing diagnosis process

Figure 2 - Interface of critical thinking in holistic care, teaching and research 


\section{FINAL CONSIDERATIONS}

We end this theoretical reflection with the certainty that the Jean Watson's theory, associated with other theories, such as Wanda Horta and authors like Capra and Facione, has fundamental importance in the nursing holistic critical thinking (HCT). In addition, this theory can decisively contribute to fill the knowledge gaps related to holistic dimension in the implementation of the NDP and clinical decision-making of students and nurses.

However, Watson's theory needs to be explored in deeper in formation spaces, not only qualifying and giving support to nursing education, but mainly contributing to the thought modeling of future nurses, to reflect directly the care process in different contexts of formation/education, assistance and research. So, the care and teaching spaces become more human, ethical, aesthetic and solidary.
We must still demonstrate the importance of thinking critically, including the holistic dimension of care in the reflection of the teachers, nursing academics and nursing professionals, rethinking the dominant paradigms in health and education fields. To do so, researches must be developed to identify the quality of the diagnostic process by applying the holistic critical thinking, proving the accuracy and assertiveness in the priority diagnoses selection that make sense for the people involved in the care process.

And even more urgent is the revaluation of current Brazilian National Curricular Guidelines, recommending the necessary focus on holistic thinking to correct mistakes and shortcomings present these days. When analyzing the curricular configuration of the different nursing schools, the lack of standardization and the limited approach of nursing theories and philosophy in care practices is evident.

\section{REFERENCES}

1. Brasil. Resolução CNE/CES n 3, de 7 de novembro de 2001: Institui as Diretrizes Curriculares Nacionais do Curso de Graduação em Enfermagem, 2001.

2. Crossetti MGO, Goes MGO. Habilidades de pensamento crítico no processo diagnóstico de enfermagem. In: Herdman TH, (Org.). PRONANDA: Programa de Atualização em Diagnósticos de Enfermagem. Porto Alegre: Artmed Panamericana; 2016;4(1):9-34.

3. Capra F. Ponto de mutação. São Paulo: Cultrix; 2006.

4. McEwen M, Willis EM. Bases teóricas de Enfermagem. 4 ed. Porto Alegre: Artmed; 2016.

5. Clark CS. Watson's human caring theory: pertinent transpersonal and humanities concepts for educators. Humanities [Internet]. 2016[cited 2017 Jan 02];5(21):1-12. Available from: http://www.mdpi.com/2076-0787/5/2/21

6. Watson J. The Philosophy and science of caring. Boulder, CO: University Press of Colorado; 2008.

7. Crossetti MGO, Lima AAA. Aplicação do modelo teórico de pensamento crítico no ensino do processo diagnóstico em enfermagem: uma experiência na prática clínica. Invest Qual Saúde [Internet]. 2016 [cited 2017 Jan 02];(2):552-61. Available from: http// proceedings.ciaiq.org/index.php/ciaiq2016/article/download/794/780

8. Menezes SSC, Corrêa CG, Silva RCG, Cruz DALM. Clinical reasoning in undergraduate nursing education: a scoping review. Rev Esc Enferm USP [Internet]. 2015 [cited 2017 Jan 02];49(6):1037-44. Available from: http://www.scielo.br/pdf/reeusp/v49n6/0080-6234-reeusp-49-06-1037.pdf

9. Facione PA, Gittens CA. Think Critically. Chapter 1. Califórnia, CA: Pearson Education; 2016.

10. Facione PA. Critical Thinking: A Statement of expert consensus for proposes of educational assessment and instruction [Internet]. California Academic Press. 1990[cited 2017 Jan 02];(1):1-20. Available from: https://assessment.trinity.duke.edu/documents/Delphi_Report.pdf 